\title{
RESULTS OF THE STUDY OF THE SIBERIAN TROUT LILY IN THE SIBERIAN REGION
}

\author{
Sedelnikova L. L. \\ Central Siberian Botanical Garden, Siberian Branch \\ of the Russian Academy of Sciences, \\ Novosibirsk,Russia,e-mail: lusedelnikova@yandex.ru
}

The results of the long-term introduction study of the Siberian Trout Lily (Erythronium sibiricum) - a rare species for Siberian and Altai natural flora, were analyzed. The seasonal rhythm of the species is presented, with a short aboveground development (1.5-2.0 months), forced summer rest of underground organs (4.5-5.0 months) and a long winter rest (6.0-6.5 months). The age-related ontogenetic states of plants in the forest-steppe zone of Western Siberia were studied. For the first time, a rhizomatous-bulbous biomorph was presented in E. sibiricum with an annually renewed bulb and a long-term short rhizome. Ontomorphogenesis was described and it is established that during seed reproduction, the generative period in individuals begins in the sixth year. The results of the age status of individuals in the natural habitats of the Kemerovo, Tomsk, and Novosibirsk regions were obtained. The quantitative composition of biologically active and spare substances, ash content, nitrogen, phosphorus, and sulfur in leaves and bulbs was determined. It is noted that the bulbs are rich in starch (32.99-49.77\%) and saponins $(9.87-15.11 \%)$. The leaves are dominated by a high content of ascorbic acid $64.7-134 \mathrm{mg} \%$, flavonols (2.1-2.6\%), sugars (25.1-43.7\%) and protopectins (3.4-4.8\%). For the first time, the content of nitrogen, phosphorus, sulfur and ash content in the leaves in the spring period was revealed and it was shown that there is an increase in the elements in the series: $\mathrm{S}<\mathrm{P}<\mathrm{N}<$ ash content. The variability of flowers' shape and color in nature and culture was recorded.

Key words: Erythronium sibiricum, distribution, reproductive capacity, life form, secondary metabolites, chemical elements, introduction, Western Siberia.

УДК 635.9

doi:10.31360/2225-3068-2021-76-66-80

\section{СОСТАВ И СОСТОЯНИЕ КОЛЛЕКЦИИ МНОГОЛЕТНИХ ТРАВЯНИСТЫХ ЦВЕТОЧНЫХ КУЛЬТУР ФИЦ СНЦ РАН}

\author{
Слепченко Н. А., Пащенко О. И. \\ Федеральное государственное бюджетное учреждение науки \\ «Федеральный исследовательский иенттр \\ "Субтропический научный иентр Российской академии наук», \\ 2. Сочи, Россия, e-mail: slepchenko@vniisubtrop.ru
}

В ФИЦ СНЦ РАН изучаются новые виды и сорта декоративных растений с целью расширения ассортимента и внедрения их в практику декоративного садоводства, а также промышленного выращивания срезочной цветочной 
продукции в цветоводческих хозяйствах. В состав коллекции многолетних травянистых растений Центра входят представители 8 семейств: Ranunculaceae, Xanthorrhoeaceae, Cannaceae, Paeoniaceae, Asparagaceae, Amaryllidaceae, Caryophyllaceae, Compositae. Они включают декоративные растения с широкой цветовой гаммой окрасок, разнообразные по форме, срокам, обильности и длительности цветения. Подобрав группы растений из данных коллекций, сменяющие друг друга по срокам цветения, можно получить непрерывно и продолжительно цветущую клумбу с ранней весны до поздней осени.

Ключевые слова: интродукция, коллекция, сорт, многолетние травянистые культуры, Ranunculaceae, Xanthorrhoeaceae, Cannaceae, Paeoniaceae, Asparagaceae, Amaryllidaceae, Caryophyllaceae, Compositae.

Человек с давних пор старается окружить себя прекрасным. Возделывание растений, а особенно красивоцветущих, является своего рода антидепрессантом. Цветочно-декоративные растения являются неотъемлемой частью жизни большинства людей. Это и комнатные растения, и горшечные, и, конечно, растения, используемые в озеленении. Особой популярностью пользуются многолетние цветочные культуры. В большинстве своем они известны давно, однако используются не в полной мере, сортимент постоянно обновляется, выводятся новые оригинальные и устойчивые сорта.

Для изучения и сохранения сложившихся генотипов в научных учреждениях, ботанических садах и у цветоводов-любителей создаются коллекции. Интродукция и селекция - источники, которые их обновляют и пополняют [37]. Коллекции живых растений, в том числе и цветочно-декоративных, являются основной базой для проведения научных исследований. Они создаются для сохранения и изучения генетического разнообразия, проведения широкого спектра фундаментальных и прикладных исследований, селекционной работы [39].

В Федеральном исследовательском центре «Субтропический научный центр Российской академии наук» (ФИЦ СНЦ РАН) (ранее ВНИИ цветоводства и субтропических культур и НИИ горного садоводства и цветоводства) создание, пополнение и поддержание генетических коллекций являются одними из важных направлений исследований. Многолетние травянистые цветочные культуры, наравне с луковичными и клубнелуковичными, поддерживаются и испытываются в зоне влажных субтропиков России [40]. Работы по интродукции и изучению цветочно-декоративных культур проводятся с 60-х годов прошлого столетия [33, 34, 43]. В последние годы коллекции пополнились новыми образцами и культурами [36]. 
Учёными Центра проводилась и продолжает проводиться работа по привлечению нового ассортимента изучаемых культур, исследованию и оценке их устойчивости в условиях влажных субтропиков, разработке и совершенствованию технологий размножения и возделывания, производства посадочного материала $[4,5,8,12,14,18,20,28,30]$. Имеющиеся в коллекциях генотипы активно используются при проведении селекционной работы, с целью получения новых высокодекоративных, более устойчивых сортов, выделения доноров и источников хозяйственно ценных признаков [16, 26-28, 35]. Черноморское побережье России является перспективным для возделывания многих цветочных культур, как открытого, так и защищённого грунта, а также с целью получения среза цветов в зимний и ранневесенний периоды $[2,10,11,22]$.

Цель исследований - сохранить и пополнить генофонд многолетних травянистых цветочных культур, изучить их биологические особенности для расширения ассортимента, адаптивного к условиям влажных субтропиков России.

Объекты и методы исследований. Исследования проводились на коллекциях многолетних цветочных культур в условиях открытого и закрытого грунта на территории отдела агротехники и питомниководства ФИЦ СНЦ РАН.

Поставленные задачи решались на уровне полевых исследований в соответствии с Методикой первичного сортоизучения цветочных культур (1998) [1] и других общепризнанных методик [23-25]. Названия растений уточнялись согласно современной номенклатуpe (The Plant List, 2013) [45].

Результаты и их обсуждение. В настоящее время коллекция многолетних травянистых цветочных культур представлена сортообразцами из семейств: Ranunculaceae Juss., Xanthorrhoeaceae Juss., Cannaceae Juss., Paeoniaceae Raf., Asparagaceae Juss., Amaryllidaceae Jaume Saint-Hilaire, Caryophyllaceae Juss., Compositae Giseke (табл. 1).

Семейство Xanthorrhoeaceae в коллекции представлено родом гемерокаллис, лилейник, красоднев (Hemerocallis L.). Родина - Восточная Азия. Название рода происходит от греческих слов hemera - день, сутки и kallos - красота, указывающее на кратковременность цветения [44]. Большинство цветков живут один день, но за счёт формирования нескольких цветоносов с большим количеством цветков на одном растении в целом цветение одного куста достаточно продолжительное. Согласно современной ботанической номенклатуре, род включает 65 видов и разновидностей, из которых 20 приняты к использованию [45]. Виды рода распространены на Дальнем Востоке, в 
Глава 2. Интродукция и сортоизучение

Китае, Корее, Монголии, Японии, а также южных районах Восточной Сибири, Курильских островах и зоне Средиземноморья. На сегодняшний день Гемерокаллис одна из наиболее популярных, распространённых и экономически значимых цветочных декоративных культур, применяемых в городском и частном озеленении [28].

Таблица 1

\section{Состав коллекции \\ многолетних травянистых цветочных культур ФИЦ СНЦ РАН}

\begin{tabular}{|c|c|c|c|}
\hline \multirow[b]{2}{*}{ Семейство } & \multirow[b]{2}{*}{ Род } & \multicolumn{2}{|c|}{ Количество, шит. } \\
\hline & & $\begin{array}{l}\text { сортов } \\
\text { (видов) }\end{array}$ & $\begin{array}{c}\text { гибридных или } \\
\text { садовых форм }\end{array}$ \\
\hline Xanthorrhoeaceae & Hemerocallis $\times$ hybrida & 10 & 420 \\
\hline \multirow{4}{*}{ Ranunculaceae } & Anemone coronaria & 25 & \\
\hline & Anemone blanda & 2 & \\
\hline & Anemone hupehensis & 4 & \\
\hline & Ranunculus asiaticus & 4 & \\
\hline Cannaceae & Canna & 4 & \\
\hline \multirow{3}{*}{ Asparagaceae } & Liriope & 4 & 2 \\
\hline & Ophiopogon & 4 & 3 \\
\hline & Reineckea & 1 & \\
\hline Paeoniaceae & Paeonia & 10 & \\
\hline Amaryllidaceae & Agapanthus & 2 & \\
\hline Caryophyllaceae & Gypsophila paniculata & 1 & \\
\hline \multirow[t]{2}{*}{ Compositae } & Gerbera & & 15 \\
\hline & ВСЕГО & 71 & 440 \\
\hline
\end{tabular}

Гемерокаллис - многолетнее травянистое корневищное растение. Образует мощные кусты с прикорневыми широколинейными сидячими листьями, прямыми или изогнутыми дугой. Цветки достаточно крупные, собраны в соцветия от 3 до 10-15 цветков в каждом. Каждый цветок живёт не более одного дня, но эта культура отличается длительным и равномерным цветением растения в течение всего сезона, что обеспечивается обилием одновременно раскрытых цветков на одном растении. Общая продолжительность цветения куста в среднем до 30 дней. Есть группа повторноцветущих культиваров [28, 31]. Цветки крупные, диаметром до 18 см, воронковидные, разнообразные по окраске и форме. 
Коллекция ФИЦ СНЦ РАН в настоящее время состоит из 10 сортов и 420 гибридных форм Hemerocallis $\times$ hybrida, которые сгруппированы по окраске (рис. 1).
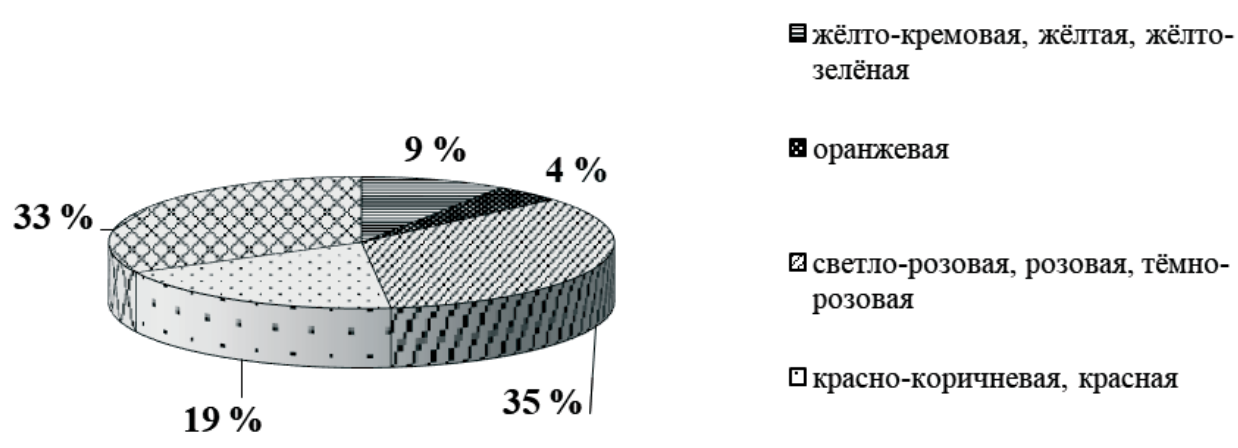

무 бордовая, бордово-фиолетовая

Рис. 1. Состав коллекции Hemerocallis $\times$ hybrida по окраске долей околоцветника

У большей части сортообразцов окраска околоцветника варьирует от светло-розовой, розовой до тёмно-розовой - 148 шт., бордовая и бордово-фиолетовая - 140 шт. Меньше всего (4 \%) в коллекции сортообразцов с оранжевой окраской - 19 шт. Также в коллекции представлены образцы с красной, красно-коричневой и жёлтой окраской.

Семейство Ranunculaceae в коллекции представлено родами Анемона, или Ветренница (Anemone L.) и Ранункулюс (Ranunculus asiaticus L.). Название рода Анемона произошло от греческого слова anemos - ветер, что связывают с особенностью у многих природных видов сбрасывать лепестки от дуновения ветра [44]. Согласно современной ботанической номенклатуре, род включает 786 видов и разновидностей, из которых 172 приняты к использованию [45]. Многочисленные виды рода распространены преимущественно в Северном полушарии, в умеренной зоне.

Анемона корончатая (Anemone coronaria L.) - многолетнее травянистое клубневое растение с декоративной розеткой ажурной листвы, высотой от 10 до 40 см. Цветы диаметром 5-10 см, разнообразные по окраске и форме с длительным сроком цветения. На одном растении развивается 8-10 до 20 цветоносов. Анемону можно использовать в озеленении, в качестве горшечной культуры, в выгонке и на срез. Большое распространение, как промышленная культура, анемона получила в Италии, Южной Франции, Англии, Голландии и Германии [7]. Сорта анемоны корончатой в Центр завезены из Нидерландов в 70-е годы XX столетия и послужили основой для создания отечественных сортов [16]. 
Глава 2. Интродукция и сортоизучение

Анемона нежная (Anemone blanda Schott \& Kotschy) - многолетнее травянистое растение высотой 7-12 см. Листья тёмно-зелёные, ажурные. Диаметр цветков 2,5-3,0 см, доли околоцветника белого, разных оттенков сиреневого и розового цветов. Количество цветоносов на одном растении 12-15 штук. Анемона нежная разрастаясь, образует небольшие, плотные куртинки. Используется в озеленении как почвопокровное растение [13, 15].

Анемона хубейская (Anemone hupehensis (Lemoine) Lemoine $=$ син. Anemone scabiosa H. Lév. \& Vaniot) была найдена в китайской провинции Хубей. Многолетнее травянистое растение с ползучими корневищами. Цветки простые, полумахровые и махровые, 5-12 см в диаметре, собраны в зонтиковидные соцветия по 15-20 шт., окраска венчика белая, кремовая, розовая, пурпурная. Цветоносы высокие, прочные, до 1,5 м высотой. Анемона хубейская используется в озеленении, для срезки и выгонки [17].

Ранункулюс азиатский (Ranunculus asiaticus L.) - название происходит от латинского rana - лягушка. Распространен в Восточном Средиземноморье, Юго-Западной Азии, Юго-Восточной Европе и Северо-Восточной Африке. Многолетнее травянистое растение высотой 45-60 см и клубнями вольцевидной формы. Листья розеточные и стеблевые, сильно опушены, тройчато-рассечённые. Цветки одиночные или собраны в небольшие соцветия, до 8 см в диаметре, махровые или полумахровые, разнообразные по окраске (белые, жёлтые, оранжевые, красные, розовые). Ранункулюс используется преимущественно для получения цветов на срез, реже в озеленении [9].

В настоящее время коллекция семейства Ranunculaceae включает 25 сортов Anemone coronaria (8 зарубежных и 17 отечественных), 2 A. blanda 'Rosea' и 'White Splendor', $4-$ A. hupehensis: 'Pamina', 'Max Vogel', 'Hadspen Abundance' и 'Andrea Atkincon' и гибридная форма, 4 сортопопуляции Ranunculus asiaticus. Сорта Anemone coronaria, особенно селекции Центра, отличаются насыщенностью и разнообразностью окраски долей околоцветника. Нами выделено четыре группы окрасок долей околоцветника: белая и пастельная, включающая кремовые и нежно-розовые оттенки; красная; розово-пурпурная и сине-фиолетовая (рис. 2). Образцы с двухцветной окраской, отнесены в группы с превалирующим цветом, например, 'Синеглазку', у которой основной цвет долей белый, но очень выразительный крупный синий центр, в сине-фиолетовые, а 'Фею’ - к розово-пурпурным (основная окраска долей розовая, центральная часть - белая). 


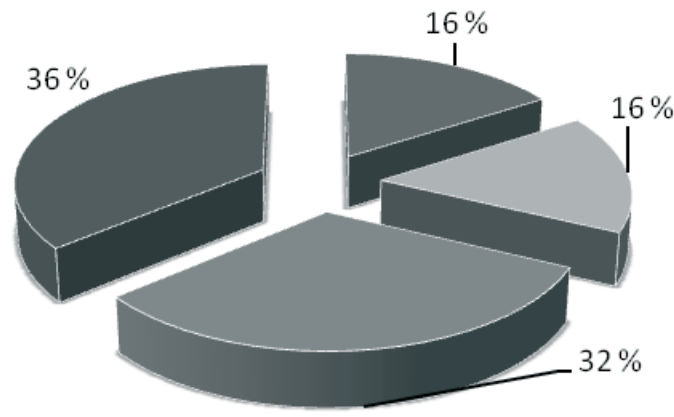

$$
\begin{aligned}
& \text { - белая и пастельная } \\
& \text { - красная } \\
& \text { - розово-пурпурная } \\
& \text { - сине-фиолетовая }
\end{aligned}
$$

Рис. 2. Состав коллекции Anemone coronaria по окраске долей околоцветника

Большая часть сортообразцов в коллекции (9 шт.) сине-фиолетовых оттенков, например, 'Волшебство', 'Свирель' и др.; 8 сортов, такие как, 'Летеница', 'Даная' и др. - розово-пурпурных оттенков. Красных сортов - 4 шт., например, 'Красная Шапочка' и 'Весенний Огонь'; белых и пастельных, таких как 'Полина' и 'The Bride'- 4 шт.

Семейство Cannaceae включает единственный род Канна (Canna L.). Название происходит от греческого слова kanna - тростник, за сходства в строении стебля. Распространён в Южной и Центральной Америке, Индии и Китае [44]. Согласно современной ботанической номенклатуре, род включает 185 видов и разновидностей, из которых 12 приняты к использованию [45]. Многолетнее травянистое клубневидно-корневищное растение высотой 1,8-2,0 м. Листья крупные, овально-продолговатые или эллиптические, зелёные, тёмно-пурпурные или бронзово-красные. Цветы жёлтого, оранжевого, красного или розового цвета, а также их сочетаний, резко-ассиметричные, 4-8 см в диаметре, собраны в кистевидное или метельчатое соцветие. Активно используется в декоративном садоводстве на юге страны, в северных районах требует специальных условий для перезимовки. Современная классификация различает сорта канн по форме цветка, высоте и габитусу растений [42].

В настоящее время коллекция Саппа включает 4 сорта 'Крымский самоцвет', 'Отблеск Заката', 'Шедевр', 'Suevia', полученные из Никитского ботанического сада [38]. Сорта в коллекции сгруппированы по окраске (рис. 3). 


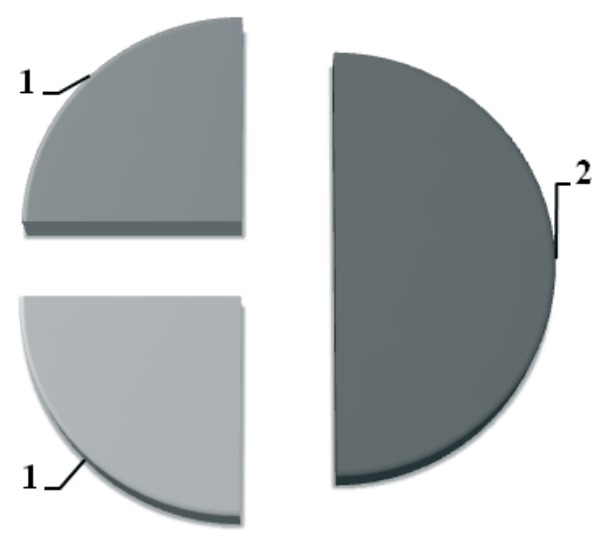

- Оранжевая

Желтая с малиновьп крапом

Фелтая

Рис. 3. Состав коллекции Canna по окраске

В коллекции 2 сорта оранжевые, 1 - жёлтый и 1 - жёлтый с малиновым крапом.

Семейство Asparagaceae представлено в коллекции родами Liriope Lour., Ophiopogon Ker Gawl. и Reineckea Kunth относятся к вечнозелёным многолетним злакоподобным растениям. Являясь близкородственными, они имеют сходные эколого-биологические и морфологические особенности, направления использования в декоративном садоводстве. В зоне влажных субтропиков России для решения проблем озеленения затенённых участков они представляют большой интерес [6, 41]. Основные направления использования - газонные покрытия, декоративные «бордюры», элементы цветочных композиций (в качестве декоративнолистных и красивоцветущих растений) $[5,19]$.

Лириопа (Liriope) название получила по имени нимфы Лириопе. Произрастает в субтропической и тропической зонах Восточной Азии [44]. Согласно современной ботанической номенклатуре, род включает 185 видов и разновидностей, из которых 12 приняты к использованию [45]. Многолетнее вечнозелёное травянистое корневищное растение. Цветы голубого, сиреневого или фиолетового цвета, мелкие, собраны в рыхлую кисть [21].

Офиопогон (Ophiopogon) название происходит от древнегреческого перевода японского названия «змеиная борода». Распространён в субтропической и тропической зонах Восточной Азии и в Гималаях [44]. Согласно современной ботанической номенклатуре, род включает 140 видов и разновидностей, из которых 67 приняты к использованию [45]. 
Многолетнее вечнозелёное травянистое корневищное растение. Цветы голубого, сиреневого или фиолетового цвета, мелкие, собраны в кисть. Имеются формы с тёмной окраской листьев [21].

Рейнекия (Reineckea) названа в честь немецкого садовода И. Рейнеке [44]. Согласно современной ботанической номенклатуре, род включает 10 видов и разновидностей, из которых 1 принят к использованию [45]. Многолетнее вечнозелёное травянистое корневищное растение. Цветки телесные, розовые или светло-фиолетовые.

Состав коллекции Центра: Лириопа (Liriope Lour): 4 вида, 2 садовые формы рода, Офиопогон (Ophiopogon Ker Gawl.): 4 видов; 3 садовые формы рода и Рейнекия (Reineckea Kunth.): 1 вид.

Семейство Paeoniaceae включает единственный род Пион (Paeonia L.). Назван по имени древнегреческого божества Пеана, врача олимпийских богов. В культуре известен с древнейших времен как декоративное и лекарственное растение [44]. Согласно современной ботанической номенклатуре, род включает 179 видов и разновидностей, из которых 36 приняты к использованию [45]. Многолетнее травянистое растение. Относятся к одной из ведущих культур открытого грунта. Цветёт весной крупными одиночными цветами простой, полумахровой или махровой формы. Разнообразны богатой цветовой гаммой: белой, розовой, красной, кремовой, бордовой и др., а также ароматом. Род включает как травянистые, так и полукустарниковые формы с несколькими стеблями, нарядной листвой. Помимо использования их в озеленении, хорошо зарекомендовали себя в срезе и выгонке [32].

В настоящее время коллекция Центра состоит из 10 сортов Paеопia, которые сгруппированы по окраске (рис. 4).

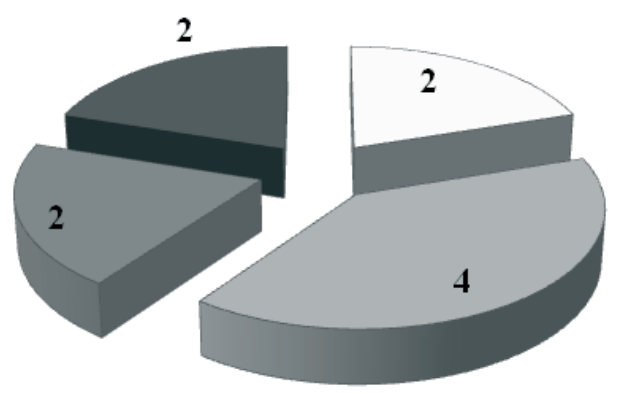

口Белая

口Светло- или бледнорозовая

чКармпново-розовая

- Малиновая

Рис. 4. Состав коллекции Paеопia по окраске 
Глава 2. Интродукция и сортоизучение

Большая часть сортов в коллекции светло- или бледно-розовых оттенков, например, 'Sweet 16', 'Mrs. Franklin D. Roosevelt'. Имеются сорта белого ('Эльбрус'), карминово-розового ('Neon') и малинового ('Орлёнок') цветов. Коллекции разнообразна не только по окраске, но и по форме цветка, а также срокам цветения.

Семейство Amaryllidaceae широко представлено в коллекции Центра луковичными растениями [36]. Агапантус (Agapanthus L'Herit.) - единственный представитель данного семейства в коллекции, имеющий корневища. Агапантус также известен под названиями африканская лилия, абиссинская красавица. Родина - Южная Африка [44]. Согласно современной ботанической номенклатуре, род включает 39 видов и разновидностей, из которых 9 приняты к использованию [45]. Многолетнее травянистое корневищное растение с розеткой длинных ремневидных листьев. Используется в озеленении, где ценят не только ажурные соцветия белого и разных оттенков сине-голубого и сиреневого цвета, но и декоративную розетку листьев [3]. Цветы диаметром 2-3 см на длинных цветоножках собраны в зонтиковидные соцветия. Цветоносы высокие, до 70 см, на одном растении развивается до 6 цветоносов. В последние годы широко используется в срезе.

В коллекции Центра две формы Agapanthus - белого и голубого цвета.

Семейство Caryophyllaceae представлено в коллекции Гипсофилой метельчатой (Gypsophila paniculata L.). Название рода происходит от греческих слов gypsos - гипс и philos - друг. Другие названия рода - качим, гипсолюбка, перекати-поле. Родина гипсофилы метельчатой Европа, Северный Кавказ, Южная Сибирь, северные районы Средней Азии, Монголия, Северо-Запад Китая [44]. Согласно современной ботанической номенклатуре, род включает 330 видов и разновидностей, из которых 152 приняты к использованию [45]. Многолетнее травянистое растение высотой до 1 м. Побеги тонкие, сильно разветвлённые. Цветы мелкие, диаметром 0,8-1,0 см, собраны в метельчатые соцветия. В период цветения куст имеет форму шара до 1 м в диаметре. Гипсофила метельчатая - прекрасная срезочная культура со своеобразным «бисерным» соцветием, предпочитающая почвы, богатые кальцием. Используется в основном для аранжировки букетов, в меньшей степени для озеленения [8]. Gypsophila paniculata представлена в коллекции махровыми сортами 'Bristol Fairy' и 'Flamingo', белого и розового цвета, соответственно.

Семейство Compositae представлено в коллекции герберой Джемсона (Gerbera jamesonii Bolus ex Hook. f.). Род Гербера (Gerbera Gronov.) был назван в честь немецкого врача и ботаника Т. Гербера. Часто её называют «трансваальской маргариткой» или «трансваальской ромашкой». 
Родина - Южная Африка [44]. Согласно современной ботанической номенклатуре, род включает 147 видов и разновидностей, из которых 40 приняты к использованию [45]. Многолетнее травянистое растение с красивыми крупными цветами. Соцветия герберы разнообразны по форме, гамме окрасок, длительно сохраняются в срезе. Пользуется неизменной популярностью и большим спросом на мировом рынке срезочных цветочных культур [35]. Низкорослые сорта используются в горшечной культуре и озеленении.

В настоящее время коллекция Центра включает 15 гибридных форм Gerbera разнообразных по окраске.

Таблица 2

\section{Сроки цветения красивоцветущих представителей многолетних травянистых цветочных культур в условиях влажных субтропиков России}

\begin{tabular}{|c|c|c|c|c|c|c|c|c|}
\hline \multirow{2}{*}{ Культура } & \multicolumn{8}{|c|}{ Период цветения } \\
\hline & III & IV & V & VI & VII & VIII & IX & $X$ \\
\hline \multicolumn{9}{|l|}{ Anemone blanda } \\
\hline \multicolumn{9}{|l|}{$\begin{array}{l}\text { Anemone } \\
\text { coronaria }\end{array}$} \\
\hline \multicolumn{9}{|l|}{$\begin{array}{l}\text { Ranunculus } \\
\text { asiaticus }\end{array}$} \\
\hline \multicolumn{9}{|l|}{ Paeonia } \\
\hline \multicolumn{9}{|l|}{ Agapanthus } \\
\hline \multicolumn{9}{|l|}{ Ophiopogon } \\
\hline \multicolumn{9}{|l|}{$\begin{array}{l}\text { Hemerocallis } \times \\
\text { hybrida }\end{array}$} \\
\hline \multicolumn{9}{|l|}{$\begin{array}{l}\text { Gypsophila } \\
\text { paniculata }\end{array}$} \\
\hline \multicolumn{9}{|l|}{ Canna } \\
\hline \multicolumn{9}{|l|}{ Gerbera } \\
\hline \multicolumn{9}{|l|}{ Liriope } \\
\hline \multicolumn{9}{|l|}{$\begin{array}{l}\text { Anemone } \\
\text { hupehensis }\end{array}$} \\
\hline Reineckea & & & & & & & & \\
\hline
\end{tabular}


Глава 2. Интродукция и сортоизучение

Многолетние травянистые растения в коллекции ФИЦ СНЦ РАН цветут с марта до конца октября. Таким образом, подобрав различные растения из данных коллекций, сменяющие друг друга по срокам и продолжительности цветения, можно получить непрерывно цветущую клумбу с продолжительным и обильным цветением с ранней весны до поздней осени (табл. 2).

Заключение. В состав коллекции многолетних травянистых растений ФИЦ СНЦ РАН входят представители 8 семейств, 13 родов. Коллекция включает декоративные растения с широкой цветовой гаммой, разнообразные по форме, срокам и длительности цветения. Изучение коллекций и рекомендация новых сортов и культур позволит расширить и усовершенствовать адаптированный ассортимент растений, используемых в различных формах цветочного оформления, озеленения, на выгонку и срез, даст толчок дальнейшему развитию отечественного цветоводства, в том числе при решении вопросов импортозамещения.

Публикация подготовлена в рамках реализации ГЗ ФИЦ СНЦ РАН № 0492-2021-0008

\section{Библиографический список}

1. Болгов В.И., Евсюкова Т.В., Козина В.В., Пустынников М.А. Методика первичного сортоизучения цветочныХ культур. - М.: РАСХН, 1998. - 40 с.

2. Болгов В.И., Мохно В.С., Евсюкова Т.В., Братухина Е.В., Козина В.В., Козина С.В., Слепченко Н.А. Выгонка луковичных и клубнелуковичных цветочных культур. Сочи: ВНИИЦиСК, 2001. - 96 с.

3. Владимирова Л.В., Новохатская О.В. Виды рода Agapanthus L'Herit. В коллекционном фонде Донецкого ботанического сада НАН Украины // Промышленная ботаника. - 2002. - Вып. 2. - С. 87-90. - ISSN 1728-6204.

4. Карпун Ю.Н., Коннов Н.А. Перспективы интродукции представителей рода Reineckia Kunth на Черноморское побережье России // Субтропическое и декоративное садоводство. - 2013. - Вып. 49. - С. 101-105. - ISSN 2225-3068.

5. Карпун Ю.Н., Коннов Н.А., Кувайцев М.В. Газон в тени. История, проблемы, рекомендации. - Сочи: СБСК, 2015. - 28 с. - ISBN 978-5-91789-198-9.

6. Келина А.В., Клемешова К.В. Наиболее распространенные проблемы газонных покрытий в зоне влажных субтропиков // Субтропическое и декоративное садоводство. - 2014. - T. 50. - C. 13-20. - ISSN 2225-3068.

7. Козина В.В. Анемона корончатая // Цветоводство. - 2015. - № 3. - С. 2-23. ISSN 0041-4905.

8. Козина В.В. Гипсофила метельчатая - основные элементы технологии выращивания // 110 лет в субтропиках России: сб. науч. тр. ВНИЦиСК- Сочи: ВНИИЦиСК, 2004. - Вып. 39. - Ч. І. - С. 170-178.

9. Козина В.В. Ранункулюс в зоне влажных субтропиков России // Субтропическое и декоративное садоводство. - 2011. - Вып. 45. - С. 69-73. - ISSN 2225-3068.

10. Козина В.В. Рекомендации по выращиванию ранневесенней срезочной продукции анемоны корончатой в теплицах и плёночных укрытиях без дополнительных технических средств. - Сочи: ВНИИЦиСК, 1998. - 16 с. 
11. Козина В.В., Клемешова К.В. Анемона корончатая - срезочная культура, использование во флористике // Субтропическое и декоративное садоводство. - 2017. - Вып. 62. - C. 172-178. - ISSN 2225-3068.

12. Козина В.В., Козина С.В. Анемона корончатая - перспективная культура // Проблемы НИР и развития субтропического и южного садоводства в 2001-2005 гг.: тезисы докл. междунар. науч.-практ. конф., г. Сочи, 1-4 октября 2001 г. Сочи: ВНИИЦиСК, 2001. - С. 216-217.

13. Козина В.В., Козина С.В. Анемона нежная на Черноморском побережье Краснодарского края // Субтропическое и декоративное садоводство. - 2017. - Вып. 63. - C. 44-49. - ISSN 2225-3068.

14. Козина В.В., Козина С.В. Коллекция рода Anemone L. в условиях влажных субтропиков // Субтропическое и декоративное садоводство. - 2018. - Вып. 66. - С. 47-57. - doi: 10.31360/2225-3068-2018-66-47-57.

15. Козина С.В. Анемона нежная в условиях влажных субтропиков России // Субтропическое и декоративное садоводство. - 2020. - Вып. 72. - С. 39-45. doi: 10.31360/2225-3068-2020-72-39-45.

16. Козина С.В. Создание сортов анемоны корончатой на Черноморском побережье Краснодарского края // Субтропическое и декоративное садоводство. - 2015. - Вып. 55. - C. 87-92. - ISSN 2225-3068.

17. Козина С.В., Козина В.В. Анемона японская в условиях влажных субтропиков России // Субтропическое и декоративное садоводство. - 2013. - Вып. 49. - С. 95-101. - ISSN 2225-3068.

18. Коннов Н.А. Офиопогон и лириопа. Перспективные газонные растения // Цветоводство. - 2014. - № 6. - С. 12-14. - ISSN 0041-4905.

19. Коннов Н.А. Применение представителей родов Liriope и Ophiopogon в декоративном садоводстве субтропической зоны России // Научные исследования в субтропиках России: сб. тр. молодых учёных, аспирантов и соискателей. - Сочи: ВНИИЦиСК, 2013. - С. 146-151. - ISBN 978-5-904533-19-9.

20. Коннов Н.А. Технология возделывания представителей рода Liriope Lour. в условиях Черноморского побережья России // Субтропическое и декоративное садоводство. - 2015. - Вып. 55. - С. 113-120. - ISSN 2225-3068.

21. Коннов Н.А., Карпун Н.Н. Особенности фенологических ритмов теневыносливых почвопокровных растений, перспективных для использования в декоративном садоводстве влажных субтропиков России // Плодоводство и виноградарство юга России. - 2020. - № 66(6). - С. 396-411. - doi: 10.30679/2219-5335-2020-6-66-396-411.

22. Кравцов И.А., Евсюкова Т.В., Козина В.В., Слепченко Н.А. Рекомендации по оценке качества цветочной продукции (гипсофила метельчатая, анемона корончатая, белоцветник летний). - Сочи: ВНИИЦиСК, 2009. - 21 с.

23. Методика государственного сортоиспытания сельскохозяйственных культур. Вып. 6 (декоративные культуры). - М.: Колос, 1968. - 224 с.

24. Методика фенологических наблюдений в ботанических садах СССР // Бюл. Гл. бот. сада. - М.: Наука. 1979. - Вып. 113. - С. 3-8.

25. Методические указания по выявлению и учету болезней цветочных культур / под ред. Т.А. Ищенко. - М.: Колос, 1974. - 16 с.

26. Мохно В.С., Братухина Е.В. Селекция цветочных культур на юге России // Плодоводство и ягодоводство России. - 2006. - Т. 15. - С. 82-84. - ISSN 2073-4948.

27. Мохно В.С., Рындин А.В., Братухина Е.В., Заверха Д.В. Селекция герберы в России // Декоративное садоводство России: сб. науч. тр. ВНИИЦиСК. - Сочи: ВНИЦиСК, 2008. - Вып. 41. - С. 223-232. 
Глава 2. Интродукция и сортоизучение

28. Пащенко О.И. Гемерокаллис гибридный (Hemerocallis $\times$ hibrida Hort.) в коллекции Всероссийского научно-исследовательского института цветоводства и субтропических культур // Субтропическое и декоративное садоводство. - 2017. - Вып. 60. - С. 43-48. - ISSN 2225-3068.

29. Пащенко О.И. Перспективные гибридные формы гемерокаллиса (Hemerocallis L.) в коллекции Всероссийского научно-исследовательского института цветоводства и субтропических культур // Субтропическое и декоративное садоводство. - 2018. Вып. 60. - С. 88-92. - ISSN 2225-3068.

30. Пащенко О.И., Слепченко Н.А. Некоторые представители семейства Xanthorrhoeaceae в коллекции Всероссийского научно-исследовательского института цветоводства и субтропических культур // Биологическое разнообразие Кавказа и Юга России: матер. XX юбил. междунар. науч. конф., г. Махачкала, 6-8 ноября 2018 г. - Махачкала: Типография ИПЭ РД, 2018. - С. 217-219. - ISBN 978-5-6041758-7-3.

31. Приходько Л.А. Краткие итоги интродукции видов рода Hemerocallis в Якутском ботаническом саду // Вестник КрасГАУ. - 2010. - № 7. - С. 30-34. - ISSN 1819-4036.

32. Реут А.А., Миронова Л.Н. Пионы. Биология и размножение. - Saarbrucken: LAP Lambert Academic Publishing GmbH\&Co.KG, 2010. - 190 c. - ISBN 978-3-8465-8489-7. 33. Рындин А.В. Генетические ресурсы субтропических, южных плодовых, цветочно-декоративных культур и возможности их использования Государственное научное учреждение Всероссийский научно-исследовательский институт цветоводства и субтропических культур Россельхозакадемии // Плодоводство и ягодоводство России. 2009. - Т. 2. - № 1. - С. 118-128. - ISSN 2073-4948.

34. Рындин А.В., Мохно В.С. Генетические ресурсы садовых растений в субтропиках России и возможности их использования // Субтропическое и декоративное садоводство. - 2012. - Вып. 47. - С. 13-22. - ISSN 2225-3068.

35. Рындин А.В., Мохно В.С. Создание новых генотипов герберы // Вестник РАСХН. - 2012. - № 5. - С. 24-26. - ISSN 0869-3730.

36. Рындин А.В., Слепченко Н.А. Генофонд цветочно-декоративных культур ФГБНУ ВНИИЦиСК: поддержание и пополнение коллекций // Научное обеспечение устойчивого развития плодоводства и декоративного садоводства: мат. междунар. науч.-практ. конф., посвященной 125-летию ВНИИЦиСК и 85-летию Ботанического сада «Дерево Дружбы», г. Сочи, 23-27 сентября 2019 г. - Сочи: ВНИИЦиСК, 2019. - С. 311-318. - ISBN 978-5-904533-32-8.

37. Рындин А.В., Слепченко Н.А. Цветочно-декоративные культуры в ФГБНУ ВНИИЦиСК: состояние и пополнение коллекций // Научные труды Северо-Кавказского федерального научного центра садоводства, виноградарства, виноделия. - 2019. - T. 25. - С. 206-210. - doi: 10.30679/2587-9847-2019-25-206-210.

38. Рындин А.В., Карпун Н.Н., Слепченко Н.А. Результаты научно-технического сотрудничества ВНИИЦиСК в 2018 году // Субтропическое и декоративное садоводство. - 2019. - Вып. 68. - С. 9-22. - doi: 10.31360/2225-3068-2019-68-9-22.

39. Рындин А.В., Келина А.В., Клемешова К.В. Использование многолетних цветочных культур в зоне влажных субтропиков России // Субтропическое и декоративное садоводство. - 2014. - Вып. 50. - С. 13-20. - ISSN 2225-3068.

40. Рындин А.В., Слепченко Н.А., Келина А.В., Клемешова К.В. 110 лет со дня рождения основоположника научной школы по цветоводству Константина Владимировича Васильева // Субтропическое и декоративное садоводство. - 2016. - Вып. 56. - C. 9-14. - ISSN 2225-3068.

41. Рындин А.В., Келина А.В., Карпун Н.Н., Клемешова К.В., Журавлёва Е.Н. Состояние и особенности ухода за газонными покрытиями в зоне влажных субтропиков России // Кормопроизводство. - 2016. - № 7. - С. 11-16. - ISSN 1562-0417. 
Субтропическое и декоративное садоводство (76)

42. Саматова Ш.А. Морфобиологические особенности канн в условиях Каршинского оазиса // Полевой журнал биолога. - 2019. - Т. 1. - № 4. - С. 202-2018. - doi: 10.18413/2658-3453-2019-1-4-202-208.

43. Слепченко Н.А., Клемешова К.В., Келина А.В. Коллекции цветочно-декоративных культур во Всероссийском научно-исследовательском институте цветоводства и субтропических культур // Цветоводство: история, теория, практика: мат. VII междунар. науч. конф., г. Минск, Беларусь, 24-26 мая 2016 г. - Минск: Конфидо, 2016. - С. 197-199. 44. Энциклопедия декоративных садовых растений [Электронный ресурс]. - 2021. Режим доступа: http://flower.onego.ru/home.html (дата обращения: 15.02.2021).

45. The Plant List. A working list of all plant species [Electronic resource] - 2021 - Access mode: http://www.theplantlist.org/ (accessed: 15.02.2021).

\title{
COMPOSITION AND CONDITION OF PERENNIAL HERBACEOUS FLOWER CROPS COLLECTION OF FRC SSC OF RAS
}

\author{
Slepchenko N. A., Paschenko O. I. \\ Federal Research Centre the Subtropical Scientific Centre \\ of the Russian Academy of Sciences, \\ Sochi, Russia,e-mail: slepchenko@vniisubtrop.ru
}

New species and cultivars of ornamental plants are being studied in the FRC SSC of RAS in order to expand the range and introduce them into the practice of ornamental gardening, as well as into the industrial cultivation of cut flower products in flower farms. The Centre's collection of perennial herbaceous plants includes representatives of 8 families: Ranunculaceae, Xanthorrhoeaceae, Cannaceae, Paeoniaceae, Asparagaceae, Amaryllidaceae, Caryophyllaceae, Compositae. They include ornamental plants with a wide range of colours, diverse in shape, flowering terms, abundance and duration of flowering. By selecting plant groups from these collections that change each other in terms of flowering, you can get a flower-bed continuously and contemporaneously blooming from early spring till late autumn.

Key words: introduction, collection, cultivar, perennial herbaceous crops, $R a$ nunculaceae, Xanthorrhoeaceae, Cannaceae, Paeoniaceae, Asparagaceae, Amaryllidaceae, Caryophyllaceae, Compositae. 